\title{
Epidemiological profile of maternal mortality
}

\author{
Perfil epidemiológico de mortalidade materna \\ Perfil epidemiológico de mortalidad materna
}

\section{Ana Claudia Sierra Martins', Lélia Souza Silva'}

'Centro Universitário Estácio de Juiz de Fora, Graduate in Nursing. Juiz de Fora, Minas Gerais, Brazil.

How to cite this article:

Martins ACS, Silva LS. Epidemiological profile of maternal mortality. Rev Bras Enferm [Internet]. 2018;71(Suppl 1):677-83.

[Thematic Issue: Contributions and challenges of nursing practices in collective health]

DOI: http://dx.doi.org/10.1590/0034-7167-2017-0624

Submission: 10-03-2017 Approval: 12-09-2017

\section{ABSTRACT}

Objective: To know the epidemiological profile of maternal mortality in Juiz de Fora, a city in the state of Minas Gerais. Data collection was carried out from April to December 2016. Method: Summary of a confidential investigation of maternal mortality on deaths occurred from January 15t, 2005 to December 31, 2015. Results: Eighty-five deaths of women residing in Juiz de Fora were identified and analyzed. The age group was between 20 and 36 years. The women carried out prenatal care $(74.1 \%)$ with less than six visits $(34.0 \%)$. Cesarean section was conducted in $38.8 \%$ of the childbirths and the obstetric treatment was considered appropriate $(32.9 \%)$. The first cause of maternal death was hypovolemic shock $12(14.10 \%)$, followed by uterine hypotony $6(7.0 \%)$. Conclusion: Cesarean section rates are high and prenatal adherence is lower than that expected, which could justify the number of deaths in the period studied.

Descriptors: Maternal Mortality; Cesarean Section; Hypovolemia; Septicemia; Epidemiology.

\section{RESUMO}

Objetivo: Conhecer o perfil epidemiológico da mortalidade materna em Juiz de Fora, Minas Gerais. A coleta de dados foi realizada de abril a dezembro de 2016. Método: Resumo da investigação confidencial de morte materna, de óbitos ocorridos entre $1^{\circ}$ de janeiro de 2005 e 31 de dezembro de 2015. Resultados: Foram identificadas e analisadas as 85 mortes de mulheres residentes em Juiz de Fora. A faixa etária foi compreendida entre 20 e 36 anos. As mulheres tiveram pré-natal $(74,1 \%)$, com menos de seis visitas $(34,0 \%)$. A cesariana foi realizada em $38,8 \%$ dos partos, e o tratamento obstétrico foi considerado correto $(32,9 \%)$. A primeira causa de morte materna foi o choque hipovolêmico $12(14,10 \%)$, seguido de hipotonia uterina $6(7,0 \%)$. Conclusão: A taxa de cesariana é alta e a aderência pré-natal é menor do que a esperada, o que poderia justificar o número de óbitos no período estudado.

Descritores: Mortalidade Materna; Cesariana; Hipovolemia; Septicemia; Epidemiologia

\section{RESUMEN}

Objetivo: Conocer el perfil epidemiológico de la mortalidad materna en Juiz de Fora, Minas Gerais. Datos recolectados de abril a diciembre de 2016. Método: Resumen de la investigación confidencia de muerte materna, de óbitos ocurridos entre el 1 de enero de 2005 y el 31 de diciembre de 2015. Resultados: Fueron identificadas y analizadas las 85 muertes de mujeres residentes en Juiz de Fora. Su faja etaria correspondía al segmento de 20 a 36 años. Las mujeres hicieron consultas prenatales $(74,1 \%)$ de menos de seis visitas $(34,0 \%)$. Se realizó cesárea en 38,8\% de los partos, y el tratamiento obstétrico fue considerado correcto (32,9\%). La primera causa de muerte materna fue el shock hipovolémico, $12(14,10 \%)$, seguido de hipotonía uterina, $6(7,0 \%)$. Conclusión: La tasa de cesáreas es alta, y la adherencia prenatal es menor a la esperada, lo cual podría justificar el número de óbitos en el período estudiado.

Descriptores: Mortalidad Materna; Cesárea; Hipovolemia; Septicemia; Epidemiología. 


\section{INTRODUCTION}

The identification of causes of maternal deaths motivated the study of the epidemiological profile of maternal mortality, as well as preventable causes, based on the improvement of the quality of care for women in the reproductive period. Maternal mortality is any death occurred during a pregnancy or after 42 days of its termination, irrespective of the site or duration of the pregnancy, due to any cause related to the worsening of the pregnancy, resulting from direct or indirect obstetric causes ${ }^{(1-2)}$.

Direct obstetric causes are related to complications during pregnancy, childbirth, or puerperium, due to inappropriate treatment, poor practice, and omissions. Indirect obstetric causes are those resulting from diseases that existed before pregnancy or a pathology developed during pregnancy, without an association with direct obstetric causes, but that worsened by specific physiological conditions of a pregnancy ${ }^{(1)}$.

The literature describes that $95 \%$ of the maternal deaths in the world could be prevented ${ }^{(3)}$ if public and private healthcare services increased sexual and reproductive rights of women, in addition to ensuring safe and respectful care ${ }^{(2)}$. The measurement of these deaths is considered an excellent indicator to measure the level of health development in the country or specific regions ${ }^{(1)}$. The maternal mortality rate is the number of deaths of women that occurred by maternal causes per 100,000 live births in a specific geographic space in the year in question ${ }^{(4)}$.

Developed countries have a maternal mortality rate of 12 maternal deaths per 100,000 live births and developing countries of 239 maternal deaths per 100,000 live births. Up to 20 maternal deaths per 100,000 live births are considered reasonable $\mathrm{e}^{(5)}$. In Brazil, in 2014, 1,552 maternal deaths per 100,000 live births were recorded, with emphasis on the southeastern regions, with 540 maternal deaths per 100,000 live births. In the state of Minas Gerais and in the city of Juiz de Fora, 111 maternal deaths and four maternal deaths per 100,000 live births were respectively recorded. High maternal mortality rate violates human rights of women and its high prevalence is focused on communities with few economic and social resources ${ }^{(1,4-5)}$.

In this context, in 1987, the Maternal Mortality Committee was established in the state of São Paulo and then, in national context, with strategic, investigative, informative, and promotion/prevention actions with a focus on reducing the high rates of maternal death ${ }^{(4)}$. The Municipal Committee for the Prevention of Maternal Mortality of Juiz de Fora (CMPMMJF, as per its acronym in Portuguese) was established in 1996 for the investigation of maternal deaths and planning of strategies to face them, based on proposals for the reflection of actions developed to women in the reproductive period ${ }^{(5)}$.

\section{OBJECTIVE}

To know the epidemiological profile of maternal mortality in the city of Juiz de Fora, based on deaths investigated by the Municipal Committee for the Prevention of Maternal Mortality of this city and calculate the maternal mortality rate from 2005 to 2015, with emphasis on the cause of death recorded in death certificates and its preventability.

\section{METHOD}

\section{Ethical aspects}

The study setting was the Municipal Committee for the Prevention of Maternal Mortality of Juiz de Fora (CMPMMJF). The present study met standards and guidelines on research involving human beings, according to resolution no. 466 of December $12,2012^{(6)}$. The project was submitted to the ethics committee of the Federal Institute of the Southeastern Minas Gerais and approved on July 27, 2016.

\section{Study design, setting, and period}

This was a quantitative, descriptive, and retrospective study, whose sample was made up of secondary data from Maternal Death Confidential Investigation Summary Files (FRICOM, as per its acronym in Portuguese), available in the CMPMMJF. The aim of descriptive studies is to determine the distribution of diseases or conditions associated with health, according to time, site, and characteristics of individuals. The purpose of the present study was to respond to the question: when, where, and who gets ill? Descriptive epidemiology can make use of secondary data by means of preexisting data of mortality and hospitalizations, for example, and primary data, that is, data collected for the development of the study ${ }^{(7)}$.

Population or sample and inclusion and exclusion criteria

The sample was made up of 85 Maternal Death Confidential Investigation Summary Files (FRICOM) from 2005 to 2015. The FRICOM consisted of a semi-structured script with the following questions: socio-educational data, development; site and number of prenatal consultations; causes of death in the death certificate and opinion of the committee: prenatal care in childbirth and puerperium; preventability and factors of death preventability; death classification: maternal, up to 42 days after pregnancy; late, from 43 days to one year after pregnancy; non-obstetric and ignored. Death classification: direct maternal obstetric; indirect obstetric; inconclusive (direct or indirect obstetric); unrelated to pregnancy. Maternal death: declared and not reported.

The inclusion criteria were deaths occurred with women residing in Juiz de Fora and investigated by the CMPMMJF from 2005 to 2015, with the presence of the FRICOM completely filled in. The exclusion criterion was the absence of these conditions. Eighty-five deaths in the age group between 20 and 36 years were identified.

\section{Study protocol}

After approval of the project by a Human Research Ethics Committee, a researcher previously trained, by means of a scale developed by the main researcher, carried out secondary data collection in the Municipal Committee for the Prevention of Maternal Mortality of Juiz de Fora, based on the FRICOM, from August 2016 to March 2017. Confidentiality and anonymity of the data was ensured.

The variables studied were: socio-educational data, development; site and number of prenatal consultations; causes of death in the death certificate and opinion of the committee: 
prenatal care in childbirth and puerperium; preventability and factors of death preventability; death classification:

\section{Analysis of the results and statistics}

The data were analyzed using Excel ${ }^{\circledR}$ 2007. Central measures were calculated for continuous variables and frequency measures for categorical variables.

The following tables were developed: historical series of the records of maternal deaths; distribution of sociodemographic aspects and related to pregnancy and childbirth of cases of maternal deaths of women residents; number of live births, maternal deaths and maternal mortality rate; death preventability; first cause of death in the city of Juiz de Fora, state of Minas Gerais, Brazil, from 2005 to 2015.

\section{RESULTS}

During the period of this study, 71,054 births in the city of Juiz de Fora were considered, all from women residing in the city. Eighty-five maternal deaths were identified in the period, which was a higher number than that found in the historical series of 1996 to 2008, when 89,068 births and 81 maternal deaths were recorded ${ }^{(2)}$.

The increase in notifications of deaths of women residing in Juiz de Fora has an association with the continuous increase in the rate of cesarean sections in the city, which was $59.15 \%$ in the period studied, being higher than the $51.24 \%$ found in Brazil. This indicator enables to evaluate the quality of the care provided, since an increase in the number of deaths can reflect in inappropriate prenatal follow-up or wrong indications for surgical childbirth ${ }^{(6)}$.

In 2013, there was an emphasis on the higher number of records, that is, $13(15.29 \%)$ maternal deaths, followed by 2011, which was the year with the lowest number of records, that is, $3(3.53 \%)$ maternal deaths. This was a significant drop compared to the previous year, 2010, when 8 (9.41) maternal deaths were notified, as shown in Table 1.

Table 1 - Distribution of records of maternal deaths, Juiz de Fora, Minas Gerais, Brazil, 2005 to 2015

\begin{tabular}{ccc}
\hline Year & Deaths recorded & \% \\
\hline 2005 & 6 & 7.06 \\
2006 & 7 & 8.24 \\
2007 & 7 & 8.24 \\
2008 & 6 & 7.06 \\
2009 & 11 & 12.94 \\
2010 & 8 & 9.41 \\
2011 & 3 & 3.53 \\
2012 & 4 & 4.71 \\
2013 & 13 & 15.29 \\
2014 & 11 & 12.94 \\
2015 & 9 & 10.58 \\
Total & 85 & 100.00
\end{tabular}

Source: Municipal Committee for the Prevention of Maternal Mortality of Juiz de Fora (CMPMMJF).
In the last three years (2013, 2014, and 2015), the number of deaths recorded dropped, as shown in the records of Table 1, in which an increase in death records was observed in 2013, when 13 deaths were recorded in the year.

Of the maternal deaths investigated from 2005 to 2015, the age group was between 20 and 41 years, representing 68 notifications. Regarding ethnicity and marital status, black and brown women represented 54 and single women represented 49 of the maternal deaths recorded. With regard to education, of the deceased women, 15 had elementary school and 20 had complete high school.

Regarding the number of consultations carried out and the incidence of maternal death, 29 women carried out less than six consultations, five carried out the minimum number of six consultations, 23 carried out more than six, nine did not carry out any, and 19 did not report this information in the summary file.

Table 2 - Distribution of sociodemographic aspects related to the pregnancy and childbirth of cases of maternal deaths of resident women, Juiz de Fora, Minas Gerais, Brazil, 2005 to 2015

\section{Epidemiological profile of maternal deaths}

\begin{tabular}{|c|c|c|c|}
\hline & & $\mathbf{n}$ & $\%$ \\
\hline Age group & 14-19 years & 9 & 10.60 \\
\hline & 20-41 years & 68 & 80.00 \\
\hline & 42 or older & 8 & 9.40 \\
\hline Ethnicity & White & 31 & 36.47 \\
\hline & Black/brown & 54 & 63.53 \\
\hline Marital status & Single & 49 & 57.65 \\
\hline & Married & 27 & 31.76 \\
\hline & Widowed & 3 & 3.52 \\
\hline & Divorced & 1 & 1.17 \\
\hline & Not reported & 5 & 5.90 \\
\hline Education & Complete elementary school & 15 & 17.64 \\
\hline & Incomplete elementary school & 8 & 9.42 \\
\hline & Complete high school & 20 & 23.52 \\
\hline & Incomplete high school & 9 & 10.60 \\
\hline & Complete higher education & 3 & 3.52 \\
\hline & Incomplete higher education & 3 & 3.54 \\
\hline & Not reported & 27 & 31.76 \\
\hline Prenatal & $<6$ consultations & 29 & 34.12 \\
\hline & 6 consultations & 5 & 5.88 \\
\hline & $>6$ consultations & 23 & 27.06 \\
\hline & None consultation & 09 & 10.59 \\
\hline & Not reported & 19 & 2.35 \\
\hline Type of childbirth & Cesarean section & 33 & 38.82 \\
\hline & Vaginal childbirth & 21 & 24.71 \\
\hline & Abortion & 09 & 10.59 \\
\hline & Not reported & 22 & 25.88 \\
\hline Site of death & Hospital & 66 & 77.65 \\
\hline & Home & 8 & 9.41 \\
\hline & Public road & 6 & 7.06 \\
\hline & Not reported & 5 & 5.88 \\
\hline Childbirth care & Appropriate & 28 & 32.94 \\
\hline & Inappropriate & 20 & 23.53 \\
\hline & Inconclusive & 23 & 27.06 \\
\hline & Not reported & 14 & 16.47 \\
\hline
\end{tabular}

Source: Municipal Committee for the Prevention of Maternal Mortality of Juiz de Fora (CMPMMJF). 
The main type of childbirth was cesarean section, with 33 records, followed by 21 vaginal childbirths, nine abortions, and 22 non-reported. Sixty-six deaths occurred in the hospital context, eight at home, six in public roads, and five nonreported. The committee considers that 28 childbirths were appropriately carried out, 20 were inappropriate, 23 were inconclusive, and 14 were not reported, as shown in Table 2.

In the city of Juiz de Fora, a high variance in the maternal mortality rate (MMR) was evidenced, calculated by the number of maternal deaths per 100,000 live births of mothers residing in a specific geographic space, in the year in question ${ }^{(8)}$. The MMR showed an increasing trend, with exception to 2011 with 45.9/100,000 live births and 2012 with 58.8/100,000 live births. The highest rate recorded in 10 years was in 2014 with 206.7/100,000 live births, with a trend to reduction, since in 2015, the MMR was $113.8 / 100,000$ live births. The MMR in Juiz de Fora corresponding to the period of 2005 to 2015 was 119.6/100,000 live births, as presented in Table 3 .

Table 3 - Distribution of the number of live births, maternal deaths, and maternal mortality rate, Juiz de Fora, Minas Gerais, Brazil, 2005 to 2015

\begin{tabular}{cccc}
\hline Year & LB* & Maternal death & MMR** \\
\hline 2005 & 6,488 & 6 & 92.4 \\
2006 & 6,363 & 7 & 110.0 \\
2007 & 6,186 & 7 & 113.1 \\
2008 & 6,160 & 6 & 97.4 \\
2009 & 6,321 & 11 & 174.0 \\
2010 & 6,220 & 8 & 128.0 \\
2011 & 6,533 & 3 & 45.9 \\
2012 & 6,796 & 4 & 58.8 \\
2013 & 6,495 & 13 & 200.0 \\
2014 & 6,770 & 14 & 206.7 \\
2015 & 6,722 & 09 & 113.8 \\
$2005-2015$ & 71,054 & 85 & 119.6 \\
\hline
\end{tabular}

Source: CMPMM JF/MS/SVS/DataSUS/SINASC/MG ${ }^{(9)}$.

Note: * Live births $(L B) * *$ Maternal Mortality Rate (MMR)

In Table 4, regarding the distribution of death preventability, 37 deaths (43.73\%) that occurred would be preventable; 25 deaths would be probably preventable (29.41\%), and only five deaths would be unpreventable (5.88\%).

Table 4 - Distribution of death preventability, Juiz de Fora, Minas Gerais, Brazil, 2005 to 2015

\begin{tabular}{ccc}
\hline Preventability & $\mathbf{n}$ & $\mathbf{\%}$ \\
\hline Preventable & 37 & 43.52 \\
Probably preventable & 25 & 29.41 \\
Unpreventable & 5 & 5.88 \\
Inconclusive & 7 & 8.25 \\
Not applied & 11 & 12.94 \\
Total & 85 & 100.00
\end{tabular}

Source: Municipal Committee for the Prevention of Maternal Mortality of Juiz de Fora (CMPMMJF).
The distribution of the first cause of maternal death identified in the FRICOM by the committee was septicemia with 24 records, followed by hypovolemic shock with 12 occurrences, and unknown cause with nine records, as shown in Table 5.

Table 5 - Distribution of the first cause of maternal death, Juiz de Fora, Minas Gerais, Brazil, 2005 to 2015

\begin{tabular}{ccc}
\hline Causes of death & $\mathbf{n}$ & $\mathbf{\%}$ \\
\hline Septicemia & 24 & 28,25 \\
Hypovolemic shock & 12 & 14,15 \\
Unknown & 9 & 10,60 \\
Car accident & 5 & 5,88 \\
Other causes & 35 & 41,12 \\
Total & 85 & 100,00 \\
\hline
\end{tabular}

Source: Municipal Committee for the Prevention of Maternal Mortality of Juiz de Fora (CMPMMJF).

Among the factors of death preventability, the CPMMJF understood that, in 29 cases $(34.12 \%)$, the true death preventability could not be classified; then, it was classified that 35 women $(41.18 \%)$ could be alive if they or their families had sought professional help; 23 deaths $(27.06 \%)$ were considered preventable from the institutional point of view, and finally, the committee considered that in 22 cases (25.81\%), the deaths would be avoided if the medical professional had intervened earlier in the therapy of pregnant women, considering that 54 childbirths $(63.54 \%)$ were assisted by them.

\section{DISCUSSION}

In the present study, in the analysis of the historical series from 2005 to 2015, 82 deaths of residents in Juiz de Fora were notified and investigated, being in accordance with the retrospective study carried out in 2012, between the years of 1996 and 2008, when 81 deaths were found ${ }^{(2)}$.

There was a reduction in deaths after 2013, possibly in accordance with the actions of the Brazilian Stork Network Program (Rede Cegonha, as per its acronym in Portuguese), implemented by decree no. 1459 of June 24, 2011, which introduced it into the Brazilian Unified Health System context (SUS, as per its acronym in Portuguese) ${ }^{(11)}$. There was an improvement in the care results, probably due to the organization of the maternal and child healthcare network in the city.

It is worth mentioning the 13 deaths that occurred in 2013, since they represented the highest rate of deaths investigated by the CPMMJF in the historical series of ten years (2005-2015), when the number of female inhabitants residing in Juiz de Fora was 272,223. Of this total, 269,501 (99\%) inhabitants lived in the urban area and 2,721 (1\%) in the rural area. Eighty-two deaths were notified in the urban area (96.74\%) and three deaths $(3.53 \%)$ in the rural area. The highest regional rate occurred in the northern zone of the city with 27 deaths $(31.76 \%)^{(8)}$.

The study of the determinants of maternal mortality, with a focus on groups of greater vulnerability, makes scientific production even more effective in the facing of the serious situation of death during pregnancy, childbirth, and puerperium among 
Brazilian women ${ }^{(9)}$. Therefore, the death of black, brown, and single women must be deeply investigated, since they constitute a risk group, emerging in the present study and in a descriptive study carried out in 2012 in the Information Department of the SUS, with high percentages of maternal death ${ }^{(3)}$.

A study carried out in the state of Paraná identified that women with a low income and poor education level, mainly women living in outskirts of urban areas, have less access to information and knowledge on health, especially with regard to reproductive health, making education level one of the factors responsible for the high number of maternal deaths ${ }^{(12)}$.

In a descriptive study with secondary data from the Information Department of the SUS and the Brazilian Institute of Geography and Statistics carried out from 2000 to 2009 with regard to marital status, it was identified that single women had the highest prevalence in the records, corresponding to $53.17 \%$ of the deaths ${ }^{(13)}$.

In the present study, the first cause of death was septicemia $(28.25 \%)$, followed by hypovolemic shock (14.15\%), and unknown causes $(10.60 \%)$. However, in a case-control study carried out in Barbacena, a city in the state of Minas Gerais, 276 women were evaluated, of which 92 were case and 184 were control. The hypertensive disorder was the most prevalent: $10.1 \%$ had serious hypertension, followed by $9.4 \%$ with serious pre-eclampsia. Among bleeding disorders, placental abruption was the most prevalent with $8.3 \%$, followed by postpartum hemorrhage with $0.7 \%{ }^{(14)}$.

Diagnosis of anemia during prenatal may be considered the most common maternal morbidity among pregnant women, and contributed to possible complications that can lead to maternal death ${ }^{(15)}$.

In a study carried out in the state of Goiás, 348 maternal deaths occurred in the state were analyzed from 1999 to 2005 , with a higher incidence of deaths in the age group between 20 and 29 years, representing $48.8 \%$ cases of deaths, which may be associated with the reproductive period and the high rate of cesarean sections ${ }^{(16)}$. The study agrees with the results of the present study, in which the age group between 20 and 40 years was identified with $80 \%$ of the deaths recorded.

In the present study, the MMR in 2005 was $92.4 / 100,000$ live births, increasing to $128 / 100,000$ live births in 2010, reaching 200/100,000 live births. In 2015, the MMR in the city was in decline, with the occurrence of 113/100,000 live births. In the city of São Paulo, the results were similar to those found in the present study, for the trend to reduction of the MMR, when, between 2004 and 2008, it was 49.75/100,000 live births. Between 2009 and 2013, it reached 46.81/100,000 live births. In the state of Paraná, the decreasing trend in MMR remained, which from 2009 to 2013, it jumped from 62.81/1,000 live births to $50.50 / 100,000$ live births ${ }^{(16-17)}$.

The main causes of maternal deaths in Brazil from 2000 to 2009 were: other diseases of mothers that complicated pregnancy, childbirth, and puerperium (17.10\%); eclampsia $(11.88 \%)$; pregnancy hypertension with significant proteinuria $(6.22 \%)$; postpartum bleeding $(5.86 \%)$; puerperal infection (5.18\%); and placental abruption $(4.28 \%)^{(18)}$.

In another documentary epidemiological study carried out in the Health Department of Ceará, in the Maternal Mortality
Information System database from 2001 to 2010, 356 maternal deaths were recorded and investigated, with a higher prevalence of brown women in the groups of hypertensive and hemorrhagic pathologies, corresponding to 160 (65.57\%) and $70(62.50 \%)$, respectively. Regarding marital status, single women had the highest prevalence ${ }^{(19)}$.

In a descriptive study carried out in the state of Santa Catarina, in the Mortality Information System and Live Births Information System of the Brazilian Ministry of Health, 491 maternal deaths that occurred from 1997 to 2010 were analyzed. Of these, 61 were associated with hemorrhage, corresponding to $12.42 \%$, and postpartum bleeding was the most prevalent cause with 26 deaths, followed by placental abruption with 15 , representing $67.21 \%$ of the maternal deaths ${ }^{(20)}$.

Regarding death preventability, the CMPMMJF understands that $43.52 \%$ of the deaths classified would be preventable with a greater attention to the early identification of risk factors and if obstetric care was appropriate. In a retrospective study carried out in the city of Juiz de Fora from 1996 to 2008, 81 maternal deaths recorded were analyzed and investigated by the CMPMMJF, being $64.0 \%$ of the deaths considered preventable; $16.7 \%$ probably preventable; $13.9 \%$ unpreventable, and $5.6 \%$ inconclusive $^{(2)}$.

Reproductive planning, monitoring, early diagnosis, and effective treatment of complications that may emerge during pregnancy, childbirth, and postpartum tend to reduce deaths, enabling the fundamental human right, which is the right to life ${ }^{(21-22)}$.

In 2000, during the United Nations General Assembly, 189 world leaders signed a declaration on eight Millennium Development Goals (MDGs) to improve the life of women, men, and children in their countries. One of the goals demands the reduction of maternal mortality in $75 \%$ based on the universal access to contraception up to $2015^{(23)}$.

In addition to the MDGs, from 2015, the agenda on sustainable development was established, which is more comprehensive than the previous agenda, for broadening the goals based on the reduction of inequalities and maternal mortality, understanding it as an indicator of improvement in the care and reduction of preventable maternal deaths ${ }^{(24)}$.

\section{Study limitations}

The limitations of this study stand on the inappropriate filling in of death certificates, in which the item "cause of death" was filled in as "others", generating a sub-information on the real cause of death.

\section{Contributions to the nursing, healthcare, or public policy areas}

As a contribution, the present study strengthens the importance of the maternal death investigation by the Municipal Committee for the Prevention of Maternal Mortality and promotes a reflection on the care provided to women during pregnancy and postpartum.

\section{CONCLUSION}

When searching for academic publications related to maternal mortality, little interest in the production and updates of 
new data on the theme is seen, highlighting the need for encouraging further studies for future publications. With regard to the present study, the results presented a high rate of maternal mortality in the city of Juiz de Fora/MG, directly reaching pregnant and puerperal women who present socioeconomic vulnerability.

The present study also showed the main factors associated with death, considering cross-sector causes and medical care provided to pregnant and puerperal women. It was evidenced that, mostly, the occurrence of childbirths and deaths occurred in the hospital environment. The results showed problems in the organization of the healthcare system, thus bringing the doubt on the quality of the care provided, evidencing the need for governmental investments for the training and qualification of professionals who provide care to women in fertile age in prenatal, childbirth, abortion, and puerperium.
The data are more relevant when it is observed that most deaths could be avoided according to the evaluation of the CMPMMJF, which shows failures directly related to the care for women during pregnancy and puerperium. Due to the current setting, the need for implementation of public policies directed to women's health is evident, aiming to provide comprehensive care to pregnant/puerperal women, establishing prevention and promotion measures to the health of the target population.

Behaviors that aim at improving life conditions of pregnant/puerperal women must have a greater emphasis, with the purpose of minimizing maternal death rates, considering its occurrence not only as a health problem of difficult resolution, but evaluating socioeconomic indicators and tracking groups of social vulnerability. The present study contributes to the epidemiological update of deaths occurred in Juiz de Fora, with the aim of providing tools for improving the care provided to the city.

\section{REFERENCES}

1. Ferraz L, Bordignon M. Mortalidade materna no Brasil: uma realidade que precisa melhorar. Rev Baiana Saúde Pública [Internet]. 2012 [cited 2017 Apr 05];36(2):527-38. Available from: http://files.bvs.br/upload/S/0100-0233/2012/v36n2/a3253.pdf

2. Faria DR, Sousa RC, Costa TJNM, Leite ICG. Mortalidade materna em cidade-polo de assistência na região Sudeste: tendência temporal e determinantes sociais. Rev Méd Minas Gerais [Internet]. 2012 [cited 2017 Apr 20];22(1):1-128. Available from: http:// www.rmmg.org/artigo/detalhes/121

3. Brasil. Ministério da Saúde. Manual dos Comitês de Mortalidade Materna. 3a ed. Brasília: Ministério da Saúde [Internet]. 2009 [cited 2017 Feb 17]. Available from: http://bvsms.saude.gov.br/bvs/publicacoes/manual_comites_mortalidade_materna.pdf

4. Juiz de Fora. Prefeitura Municipal. Secretaria Municipal de Saúde. Plano de Saúde de 2014-2017: Juiz de Fora [Internet]. 2017 [cited 2017 Apr 20]. Available from: https://www.pjf.mg.gov.br/conselhos/saude/plano.php

5. World Health Organization. WHO. Maternal mortality [Internet]. 2016 [cited 2017 Dec 14]. Available from: http://www.who.int/ mediacentre/factsheets/fs348/en/

6. Brasil. Conselho Nacional de Saúde. Resolução No 466, de 12 de dezembro de 2012. Aprova as diretrizes e normas regulamentadoras de pesquisas envolvendo seres humanos: [Internet]. 2012 [cited 2017 Feb 15]. Available from: http://conselho. saude.gov.br/resolucoes/2012/Reso466.pdf

7. Szklo M, Javier Nieto F. Basic study designs in analytical epidemiology. In: Szklo M, Javier Nieto F. Epidemiology: beyond the basics. Gaithersburg: Aspen Publishers Inc: 3-51[Internet]. 2000. [cited 2017 Feb 17]. Available from: https://catalyst.library.jhu. edu/catalog/bib_2629589

8. Brasil. Departamento de Informática do Sistema Único de Saúde - Datasus. Nascidos vivos Brasil. [Internet]. 2017 [cited 2017 Jul 11]. Available from: http://tabnet.datasus.gov.br/cgi/tabcgi.exe?sinasc/cnv/nvuf.def

9. Brasil. Departamento de Informática do Sistema Único de Saúde - Datasus. Dados de saúde. [Internet]. 2015[cited 2016 Dec 20] Available from: http://www2.datasus.gov.br/datasus/index.php?area0205

10. Brasil. Ministério da Saúde. Gabinete do Ministro. Portaria № 1459 de 24 de junho de 2011. Institui no âmbito do Sistema Único de Saúde (SUS) a Rede Cegonha [Internet] 2011[cited 2017 Jan 20] Available from: http://bvsms.saude.gov.br/bvs/saudelegis/ gm/2011/prt1459_24_06_2011.html

11. Morse ML, Fonseca SC, Barbosa MD, Calil MD, Eyer FPC. Mortalidade Materna no Brasil: o que mostra a produção científica nos últimos 30 anos? Cad Saúde Pública [Internet]. 2008 [cited 2016 Nov 15];27(4):623-38. Available from: http://www.scielo. $\mathrm{br} / \mathrm{pdf} / \mathrm{csp} / \mathrm{v} 27 \mathrm{n} 4 / 02 . \mathrm{pdf}$

12. Brasil. Instituto Brasileiro de Geografia e Estatística IBGE. Censo Demográfico 2010. Estimativa por População 2016 [Internet]. 2016[cited 2017 Jan 17]. Available from: http://cidades.ibge.gov.br/xtras/temas.php?lang\&codmun313670\&idtema130\&searchm inas-gerais | juiz-de-fora| estimativa-da-populacao-2016

13. Vidal CEL, Carvalho MAB, Grimaldi IR, Reis MCR, Baêta MCN, Garcia RB, et al. Morbidade materna grave na microrregião de Barbacena/MG. Cad Saúde Colet [Internet]. 2016 [cited 2016 Dec 20];24(2). Available from: http://www.scielo.br/pdf/cadsc/ v24n2/1414-462X-cadsc-24-2-131.pdf

14. Institute for Health Metrics and Evaluation. IHME. The Global Burden of Disease: Generating Evidence, Guiding Policy. Seattle, WA: IHME. [Internet]. 2013 [cited 2017 Jan 10]. Available from: http://www.healthdata.org/sites/default/files/files/policy_report/2013/ 
GBD_GeneratingEvidence/IHME_GBD_GeneratingEvidence_FullReport.pdf

15. Prudente LAR. Indicadores de mortalidade materna em Goiás no período de 1999 a 2005: implicações para a enfermagem [Dissertação]. Faculdade de Enfermagem. Universidade Federal de Goiás. [Internet]. 2008 [cited 2017 Jan 10]. Available from: https://ppgenf.fen.ufg.br/up/127/o/Lorena_de_Almeida_Ribeiro_Prudente.pdf

16. Martins $M$, Monticelli $M$, Brüggemann OM, Costa R. A produção de conhecimento sobre hipertensão gestacional na pósgraduação stricto sensu da enfermagem brasileira. Rev Esc Enferm USP [Internet]. 2012[cited 2017 Jan 2];46(4):802-8. Available from: http://www.scielo.br/pdf/reeusp/v46n4/en_03.pdf

17. Sousa DMN, Mendes IC, Oliveira ET, Chagas ACMA, Catunda HLO, Oriá MOB. Mortalidade materna por causas hipertensivas e hemorrágicas: análise epidemiológica de uma década. Rev Enferm UERJ [Internet]. 2014[cited 2017 Feb 14];22(4):500-6. Available from: http://www.e-publicacoes.uerj.br/index.php/enfermagemuerj/article/view/15314

18. Áfio ACE, Araújo MAL, Rocha AFB, Andrade RFV, Melo SP. Óbitos maternos: necessidade de repensar estratégias de enfrentamento. Rev Rene [Internet]. 2014 [cited 2017 May 03];15(4):631-8. Available from: http://www.repositorio.ufc.br/handle/riufc/11408

19. Martins HEL, Souza ML, Arzuaga-Salazar MA. Mortalidade materna por hemorragia no Estado de Santa Catarina, Brasil. Rev Esc Enferm USP [Internet]. 2013[cited 2017 Mar 13];47(5):1025-30. Available from: http://www.scielo.br/pdf/reeusp/v47n5/pt_00806234-reeusp-47-05-1025.pdf

20. Vega CEP, Soares VMN, Lourenço FNAM. Mortalidade materna tardia: comparação de dois comitês de mortalidade materna no Brasil. Cad Saúde Pública [Internet]. 2017 [cited 2017 Jul 09];33(3):e00197315 Available from: http://www.scielo.br/pdf/csp/ v33n3/1678-4464-csp-33-03-e00197315.pdf

21. Firmino NF. Supremo Tribunal Federal: um olhar para a interpretação constitucional. Âmbito Jurídico [Internet]. 2016 [cited 2017 Jul 22];19(151):1202-07. Available from: http://ambito-juridico.com.br/site/?n_link = revista_artigos_leitura\&artigo_id=17656

22. Bustreo F, Say L, Koblinsky M, Pullum T W, Temmerman M, et al. Ending Preventable Maternal Deaths: The Time Is Now. Lancet Glob Health [Internet]. 2013 [cited 2017 Jul 22];1(4):E176-77.Available from: http://www.thelancet.com/journals/langlo/article/ PIIS2214-109X(13)70059-7/abstract

23. Gilmore K, Camhe Gebreyesus TA. What Will It Take to Eliminate Preventable Maternal Deaths? The Lancet [Internet]. 2012 [cited 2017 Jul 22];386(9837):87-88. Available from: https://www.ncbi.nlm.nih.gov/pubmed/22784544

24. Souza, JP. A mortalidade materna e os novos objetivos de desenvolvimento sustentável (2016-2030). Rev Bras Cinecol Obstet [internet]. 2015 [cited 2017 Jul 22]; 37(12):549-51. Available from: http://www.scielo.br/pdf/rbgo/v37n12/0100-7203-rbgo-37-12-00549.pdf 